\title{
Influence of Rosemary and Garlic on some Haematological parameters and Immunological Functions on Cirrhotic Liver Rats
}

\author{
Omnia G.Refaat ,Naeem M.Rabeh and Alaa A.Ezzat \\ Nutrition and Food Science Department, Faculty of Home Economics, \\ Helwan University.
}

\begin{abstract}
The study was conducted to investigate the effect of rosemary and garlic supplementation on some haematological parameters and immune functions in cirrhotic liver rats. Fifty two male albino rats weighing $180 \pm 5 \mathrm{~g}$ were used. The first main group $(\mathrm{n}=6)$ was fed on the basal diet during the experimental period and kept as a negative control group. The second main group $(n=46)$ was intraperitoneally injected with $\mathrm{CCl}_{4}$ at a dose of $0.5 \mathrm{ml} / 100 \mathrm{~g}$. body weight for the first time and followed by a dose of $0.3 \mathrm{ml} / 100 \mathrm{~g}$ b.w. twice a week over a period of six weeks in order to induce liver cirrhosis.Fourinjected rats were randomly chosen for pathological examination to ensure that livers become cirrhotic. The other rats $(n=42)$ were divided into 7 subgroups ( 6 rats each) as follows: Subgroup (1) was fed on basal diet as a positive control group. Subgroups (2 and 3) were fed on basal diet supplemented with $5 \%$ and $10 \%$ rosemary respectively. Subgroups (4 and 5) were fed on basal diet supplemented with $5 \%$ and $10 \%$ garlic respectively. Subgroups (6 and 7$)$ were fed on basal diet supplemented with $5 \%$ and $10 \%$ of (rosemary and garlic) at a ratio of (1:1) respectively. Rats were fed the experimental diet for a period of 8 weeks. Results indicatedthat the highest $(\operatorname{lgM})$ and $(\operatorname{lgG})$ levelsin serum were observed in the group fed combination of rosemary and garlic compared to positive control. Diets supplemented with rosemary or garlic or their combination at different levels significantly increased $(P<0.05)$ the mean levels of serum total protein, albumin and globulin respectively, compared to the control positive group. The highest increase in protein parameters concentrations were observed at the groups fed on basal diet supplemented with a mixture of rosemary and garlic. Supplementation with combination of rosemary and garlic showed significant decrease $(P<0.05)$ in the mean serum levels of (AST), (ALT) and (ALP) respectively compared to the control positive group. On the other hand, the supplementation with rosemary, garlic and their combination significantly $(P<0.05)$ increased the mean level of RBCs, WBCs, PCV and Hemoglobin compared to the positive control group. The highest increase in the tested parameters was observed at the groups that fed on a combination of rosemary and garlic.
\end{abstract}

Key Words: rosemary-garlic-antioxidant-antiinflammatory-Liver cirrhosis- immune system-hematological parameters.

\section{Introduction}

The immune system is the network of cells, tissues, and organs that work together to defend the body against attacks by "foreign" invaders. These are primarily infection-causing organisms such as 


\section{Omnia G.Refaat et al}

bacteria, viruses, parasites and fungi. Because the human body provides an ideal environment for many microbes, the immune system's job is destroying them (Delves and Roitt,2000).

Liver cirrhosis is a condition in which the liver slowly deteriorates and is unable to function normally due to chronic injury. Scar tissue replaces healthy liver tissue and partially blocks the flow of blood through the liver(Kaidoet al., 2009). As the liver fails, complications may include hypertension,edema, splenomegaly, metabolic bone diseases, insulin resistance and type 2 diabetes and liver cancer(Wielandet al., 2010).Cirrhosis can cause immune system dysfunction due to longterm malnutrition (Bonnelet al., 2011). In the past, medicinal plants were considered as the only form of health care readily available to the majority of human populations, and plants or plant derived products were used for medicinal purposes for centuries. Moreover, it was estimated that about $80 \%$ of the world population used to rely on botanical preparations as medicines to meet their health needs (Langneret al., 1998).They were generally considered as safe and proved to be effective against certain ailments (Ganguly et al., 2003). The use of medicinal plants has shown a gradual increase, especially when the scientific investigations have overwhelmed us with their medicinal potentials. Two potentials are considered important in this regard; anti-mutagenic and immune modulators (Kalpagam and Nirmala, 2003).

Dietary polyphenols have been shown to inhibit LDL oxidation, scavenge superoxide and other reactive oxygen species (ROS), and increase antioxidant capacity (Visioli et al., 2015). Furthermore, some dietary phenolic compounds, mainly polyphenols, have been shown to affect human platelet function in (vitro and in vivo) (Ostertag et al., 2010).

Rosemary (Rosmarinusofficinalis), due to its richness in essential oils and phenolic compounds together with other constituents, has attracted the investigators in the field of medicinal plants. In this regard, the crude extract of the plant and/or isolated compounds have shown immune modulator (AISereiti et al., 1999) anti-mutagenic (Alexandrov et al., 2006 and Peng et al., 2007) and anti-oxidant effects (Yesil-Celiktas et al., 2007 and Chang et al., 2008).

Garlic (Allium sativum) has a long history of use as an immune system booster because of its antiseptic, anti-fungal and nutritive properties. It is a natural detoxicant protecting against bacterial and viral infections without any of the side-effects associated with antibiotics(Ad'hiahet al., 2004).

\section{Aims of Study}

This study was conducted to investigate the effect of rosemary and garlic supplementation on some haematological parameters and immune functions in cirrhotic liver rats.

\section{Materials and Methods}

\section{Materials:--Chemicals:}

Casein, vitamins, minerals, cellulose and $\mathrm{CCl}_{4}$ was obtained from El-Gomhoria Company, Cairo, Egypt. Kits for blood analysis were purchased from Gama Trade Company, Cairo, Egypt. Plants: Fresh rosemary (Rosmarinus officinalis) and garlic (Allium sativum) were obtained from Agriculture Research Center, Giza, Egypt. Animals: Adults male albino rats $(n=52)$ of Sprague- Dawely Strain weighing (180 \pm $5 \mathrm{~g}$ ) were purchased from Helwan Farm for Experimental Animals, Helwan, Egypt .

\section{Methods:}




\section{Egypt. J. of Nutrition and Health Vol. 14 No. 1 January (2019)}

Preparation of dried rosemary and garlic: fresh rosemary and garlic were cleaned, washed, dried by solar energy at the National Research Center, Dokki, Egypt and were well grinded to get the fine powder.

\section{Experimental Design:}

Fifty two rats were housed in well aerated cages under hygienic conditions and fed on basal diet for one week for adaptation. The diet was formulated according to (Reeves et al., 1993). After this week rats were divided into two main groups as follows:-

The first main group $(n=6)$ was fed on the basal diet during the whole experimental period and kept as a negative control group.

The second main group $(\mathrm{n}=46)$ was injected intraperitoneally with $\mathrm{CCl}_{4}$ at a dose of $0.5 \mathrm{ml} / 100 \mathrm{~g}$. body weight for the first time and after one week at a dose of $0.3 \mathrm{ml} / 100 \mathrm{~g} \mathrm{b.w}$. twice a week over a period of six weeks in order to induce liver cirrhosis (Zhao et al., 2014). Four rats from the injected rats were chosen randomly and slain and the liver were subjected to pathological examination to ensure that livers become cirrhotic. The other rats $(n=42)$ were divided into 7 subgroups ( 6 rats each) as follows:

Subgroup (1) was fed on basal diet as a positive control group.

Subgroups (2 and 3) were fed on basal diet supplemented with $5 \%$ and $10 \%$ rosemary respectively.

Subgroups (4 and 5) were fed on basal diet supplemented with $5 \%$ and $10 \%$ garlic respectively.

Subgroups ( 6 and 7 ) were fed on basal diet supplemented with $5 \%$ and $10 \%$ of (rosemary and garlic) at a ratio of $(1: 1)$ respectively.

At the end of the experiment ( 8 weeks) the rats were fasted for 12 hour, and then sacrificed under ether anesthesia. Two blood samples were collected. The first sample was collected into a tube containing EDTA as anticoagulant and used for assessment of haematological indices. The second blood sample was collected into a centrifuge tube without any anticoagulant and was centrifuged for 15 minutes at 3000 r.p.m. to obtain serum which was stored at $-20^{\circ} \mathrm{C}$ until used for subsequent analysis.

\section{Biochemical analysis:}

Immunoglobulin $\mathrm{M}(\operatorname{Ig} \mathrm{M})$ and immunoglobulin $\mathrm{G}(\mathrm{IgG})$ were measured according to (Ziva and Pannall, 1984). Total leucocytes count(WBC), red blood cell (RBC) count, haemoglobin concentrations were estimated, and packed cell volume (PCV) was determined using standard haematological technique as described by (Ochei and Kolharktar 2008). Serum aspartate aminotransferase (AST) and alanine aminotransferase (ALT) were determined according to the method of (Reitman and Frankel, 1957) and alkaline phosphatase (ALP) according to (Roy, 1970), while, Total protein, albumin and globulin were estimated according to (Weissman et al., 1950).

Meanwhile, low density lipoprotein(LDL-C) and very low density lipoprotein(VLDL-C) were calculated according to (fridewald et al.,1972). Serum total cholesterol (TC) (Richmond,1973) ,triglycerides (TG)(Whalefeid,1974) , high density lipoprotein(HDL-C) (Albers et al .,1983) were determined.

\section{Statistical analysis:}

The obtained results were analyzed according to SPSS program, version (18). ANOVA test was used to compare results among groups and $\mathrm{P}<0.05$ was considered to be significant (Artimage and Berry, 1987). 


\section{Omnia G.Refaat et al}

\section{Results}

Table (1):

The crude chemical composition of rosemary and garlic .

\begin{tabular}{|c|c|c|c|}
\hline & Nutrients (/100 g) & Rosemary & Garlic \\
\hline \multirow{7}{*}{$\begin{array}{c}\text { Macro } \\
\text { nutrients }\end{array}$} & Calories (k.cal) & 331 & 203 \\
\hline & Proteins (g) & 4.9 & 8.6 \\
\hline & Fats $(g)$ & 15 & 0.7 \\
\hline & omega-3(g) & 1.1 & 27.2 \\
\hline & omega-6(g) & 1.2 & 311 \\
\hline & Carbohydate (g) & 64 & 45 \\
\hline & Total fiber (g) & 43 & 2.7 \\
\hline \multirow{2}{*}{ Vitamins } & Vitamin A (IU) & 312 & 12.2 \\
\hline & Vitamin C (mg) & 61 & 42.4 \\
\hline \multirow{3}{*}{ Minerals } & zinc (mg) & 3.2 & 1.6 \\
\hline & Iron (mg) & 29 & 2.3 \\
\hline & Selenium & 0.46 & 0.19 \\
\hline
\end{tabular}

The chemical composition of rosemary and garlic as shown in Table (1) indicated that, rosemary is high in (calories, carbohydrates,total fat, total fiber, vitamin $\mathrm{A}$, vitamin $\mathrm{C}$ and iron) but low in protein, zinc and selenium. While garlic is lesser in calories, carbohydrates and vitamin $\mathrm{C}$ but low in vitamin $\mathrm{A}$, iron ,zinc and selenium However, it is highel in total fat,omega-3 and,omega- 6 fatty acids .

Table (2):

Effect of rosemary and garlic on serum IgG and IgM in rats with induced liver cirrhosis.

\begin{tabular}{|c|c|c|}
\hline $\begin{array}{ll}\text { Groups } & \text { Parameters }\end{array}$ & $\lg G(\mathrm{mg} / \mathrm{ml})$ & $\lg \mathrm{M}(\mathrm{mg} / \mathrm{ml})$ \\
\hline Control (-ve) & $5.35 \pm 0.22^{a}$ & $3.93 \pm 0.03^{a}$ \\
\hline Control (+ve) & $1.31 \pm 0.05^{\mathrm{g}}$ & $0.49 \pm 0.08^{\dagger}$ \\
\hline Rosemary 5\% & $2.21 \pm 0.16^{\dagger}$ & $1.02 \pm 0.03^{e}$ \\
\hline Rosemary $10 \%$ & $2.95 \pm 0.13^{e}$ & $1.21 \pm 0.05^{\mathrm{e}}$ \\
\hline Garlic 5\% & $3.69 \pm 0.05^{d}$ & $1.91 \pm 0.04^{\mathrm{d}}$ \\
\hline Garlic $10 \%$ & $3.82 \pm 0.23^{d}$ & $1.99 \pm 0.06^{d}$ \\
\hline Combination 5\% & $4.30 \pm 0.17^{c}$ & $2.73 \pm 0.17^{c}$ \\
\hline Combination $10 \%$ & $4.83 \pm 0.12^{b}$ & $3.38 \pm 0.19^{b}$ \\
\hline
\end{tabular}

Values were expressed as Means \pm SE.

Values at the same column with different letters are significantly different at $P<0.05$.

Table (2)shows the effect of rosemary and garlic at different levels on serum immunoglobulins (IgM and $\mathrm{lgG}$ ) of rats with induced liver cirrhosis. The injection with $\mathrm{CCl}_{4}$ induced immune deficiency in rats. There are significant decrease $(\mathrm{P}<0.05)$ in the mean value of $\lg \mathrm{M}$ and $\lg \mathrm{G}$ compared to the negative control group. Diets supplemented with rosemary showed significant increase $(P<0.05)$ in the mean levels of $\operatorname{lgM}$ and $\lg G$, respectively compared to the positive control group.On adding garlic it showed significant difference $(P<0.05)$ in the mean levels of $\lg M$ and $\lg G$, compared to the control positive group. There was a significant difference $(P<0.05)$ in the level of $\lg M$ and $\lg G$ among the groups that fed on the different levels of rosemary,garlic and combination of rosemary and garlic. The highest IgM and IgG level are observed in groups fed combination of rosemary and garlic. 
Egypt. J. of Nutrition and Health Vol. 14 No. 1 January (2019)

Table (3):

Effect of rosemary and garlic on serum total protein, albumin and globulin in rats with induced liver cirrhosis.

\begin{tabular}{l|c|c|c}
\hline \multirow{2}{*}{ Groups } & Total protein & Albumin & Globulin \\
\cline { 2 - 4 } & \multicolumn{3}{|c}{$(\mathrm{g} / \mathrm{dl})$} \\
\hline Control (-ve) & $12.26 \pm 0.14^{\mathrm{a}}$ & $6.10 \pm 0.17^{\mathrm{a}}$ & $6.96 \pm 0.08^{\mathrm{a}}$ \\
\hline Control (+ve) & $4.83 \pm 0.38^{\mathrm{f}}$ & $2.18 \pm 0.12^{\mathrm{f}}$ & $1.20 \pm 0.25^{\mathrm{g}}$ \\
\hline Rosemary 5\% & $6.73 \pm 0.37^{\mathrm{e}}$ & $2.99 \pm 0.12^{\mathrm{e}}$ & $2.63 \pm 0.31^{\dagger}$ \\
\hline Rosemary 10\% & $8.00 \pm 0.51^{\mathrm{d}}$ & $3.68 \pm 0.10^{\mathrm{d}}$ & $3.50 \pm 0.20^{\mathrm{e}}$ \\
\hline Garlic 5\% & $8.53 \pm 0.29^{\mathrm{cd}}$ & $3.86 \pm 0.18^{\mathrm{d}}$ & $4.33 \pm 0.28^{\mathrm{d}}$ \\
\hline Garlic 10\% & $9.13 \pm 0.07^{\mathrm{C}}$ & $4.03 \pm 0.08^{\mathrm{d}}$ & $5.43 \pm 0.08^{\mathrm{c}}$ \\
\hline Combination 5\% & $10.60 \pm 0.23^{\mathrm{b}}$ & $4.73 \pm 0.21^{\mathrm{c}}$ & $5.90 \pm 0.05^{\mathrm{bc}}$ \\
\hline Combination 10\% & $11.26 \pm 0.14^{\mathrm{b}}$ & $5.55 \pm 0.18^{\mathrm{b}}$ & $6.30 \pm 0.20^{\mathrm{b}}$ \\
\hline
\end{tabular}

Values were expressed as Means \pm SE.

Values at the same column with different letters are significantly different at $\mathrm{P}<0.05$.

Data in table (3) shows the effect of rosemary and garlic at different levels on serum protein parameters (total protein, albumin and globulin) in rats with induced liver cirrhosis. Diets supplemented with rosemary or garlic or their combination at different levels significantly increased $(P<0.05)$ the mean levels of total protein, albumin and globulin respectively, compared to the positive control group. The highest increase in protein parameters concentrations were observed at the groups fed on basal diet supplemented with a mixture of rosemary and garlic.

Table (4):

Effect of rosemary and garlic on liver functions of rats with induced liver cirrhosis.

\begin{tabular}{l|c|c|c}
\hline \multirow{2}{*}{ Groups } & AST & ALT & ALP \\
\cline { 2 - 4 } & \multicolumn{3}{|c}{$(\mu / \mathrm{L})$} \\
\hline Control (-ve) & $71.60 \pm 3.59^{\mathrm{g}}$ & $25.06 \pm 2.03^{\mathrm{e}}$ & $154.43 \pm 3.05^{\dagger}$ \\
\hline Control (+ve) & $144.40 \pm 3.12^{\mathrm{a}}$ & $58.23 \pm 1.68^{\mathrm{a}}$ & $285.50 \pm 1.60^{\mathrm{a}}$ \\
\hline Rosemary 5\% & $130.66 \pm 3.17^{\mathrm{b}}$ & $50.16 \pm 1.16^{\mathrm{b}}$ & $238.70 \pm 8.37^{\mathrm{b}}$ \\
\hline Rosemary 10\% & $123.26 \pm 2.45^{\mathrm{bc}}$ & $46.40 \pm 1.13^{\mathrm{b}}$ & $221.66 \pm 3.38^{\mathrm{c}}$ \\
\hline Garlic 5\% & $117.53 \pm 2.26^{\mathrm{cd}}$ & $40.60 \pm 2.22^{\mathrm{c}}$ & $226.60 \pm 5.70^{\mathrm{bc}}$ \\
\hline Garlic 10\% & $110.66 \pm 2.33^{\mathrm{d}}$ & $38.66 \pm 0.88^{\mathrm{c}}$ & $218.53 \pm 1.57^{\mathrm{c}}$ \\
\hline Combination 5\% & $98.53 \pm 1.07^{\mathrm{e}}$ & $33.34 \pm 0.87^{\mathrm{d}}$ & $186.00 \pm 3.52^{\mathrm{d}}$ \\
\hline Combination 10\% & $88.66 \pm 2.40^{\dagger}$ & $28.16 \pm 1.01^{\mathrm{e}}$ & $170.56 \pm 2.52^{\mathrm{e}}$ \\
\hline
\end{tabular}

Values were expressed as Means \pm SE.

Values at the same column with different letters are significantly different at $\mathrm{P}<0.05$.

Results illustrated in table (4) revealed the effect of rosemary and garlic at different levels on liver functions of rats with induced liver cirrhosis. Rats injected with $\mathrm{CCl}_{4}$ (positive control rats) had significant increase $(P<0.05)$ in the mean value of serum AST,ALT and ALP compared to the negative control group. On the other hand, the supplementation with different levels of rosemary and garlic significantly decreased $(P<0.05)$ the mean level of serum liver enzymes compared with the control positive group. There are significant differences $(P<0.05)$ in the level of serum ASTand ALT between the groups that fed on diet supplemented with rosemary and garlic compared to the positive control group.Supplementation with combination of rosemary and garlic showed significant decrease $(\mathrm{P}<0.05)$ in the mean levels of AST, ALT and ALP respectively compared to the positive control group. 
Table (5):

Effect of rosemary and garlic on serum lipid profile in rats with induced liver cirrhosis.

\begin{tabular}{|c|c|c|c|c|c|}
\hline \multirow{2}{*}{ Groups } & TC & TG & HDL-C & VLDL-C & LDL-C \\
\hline & \multicolumn{5}{|c|}{$\mathrm{mg} / \mathrm{dl}$} \\
\hline Control (-ve) & $79.10 \pm 2.99^{d}$ & $45.33 \pm 2.18^{\mathrm{e}}$ & $60.16 \pm 2.24^{a}$ & $9.06 \pm 0.43^{\mathrm{e}}$ & $11.43 \pm 0.68^{\mathrm{e}}$ \\
\hline Control (+ve) & $116.16 \pm 3.63^{a}$ & $88.00 \pm 4.04^{a}$ & $34.33 \pm 2.40^{\mathrm{e}}$ & $17.60 \pm 0.80^{\mathrm{a}}$ & $64.23 \pm 1.18^{a}$ \\
\hline Rosemary 5\% & $104.80 \pm 2.31^{b}$ & $79.00 \pm 0.57^{b}$ & $43.00 \pm 1.52^{d}$ & $15.80 \pm 0.11^{b}$ & $46.00 \pm 1.10^{b}$ \\
\hline Rosemary $10 \%$ & $97.33 \pm 1.76^{c}$ & $68.67 \pm 0.88^{c}$ & $46.00 \pm 2.08^{\text {cd }}$ & $13.73 \pm 0.17^{c}$ & $37.60 \pm 3.36^{c}$ \\
\hline Garlic 5\% & $92.70 \pm 2.71^{\mathrm{C}}$ & $66.00 \pm 2.08^{c}$ & $48.40 \pm 0.94^{\text {cd }}$ & $13.20 \pm 0.41^{\mathrm{C}}$ & $31.10 \pm 1.72^{\mathrm{d}}$ \\
\hline Garlic 10\% & $90.10 \pm 1.81^{c}$ & $63.83 \pm 1.16^{\mathrm{c}}$ & $51.66 \pm 1.20^{\mathrm{bC}}$ & $12.76 \pm 0.23^{\mathrm{C}}$ & $25.66 \pm 2.47^{\mathrm{d}}$ \\
\hline Combination 5\% & $76.66 \pm 1.76^{d}$ & $57.00 \pm 1.52^{d}$ & $56.33 \pm 3.17^{\text {ab }}$ & $11.40 \pm 0.30^{\mathrm{d}}$ & $8.93 \pm 3.26^{\mathrm{et}}$ \\
\hline Combination $10 \%$ & $75.76 \pm 1.75^{d}$ & $55.66 \pm 1.85^{d}$ & $60.46 \pm 1.86^{a}$ & $11.13 \pm 0.37^{d}$ & $4.16 \pm 0.64^{\dagger}$ \\
\hline
\end{tabular}

Values were expressed as Means $\pm \mathrm{SE}$.

Values at the same column with different letters are significantly different at $\mathrm{P}<0.05$.

TC:-Total cholesterol

TG:-Triglycerides

HDL:-High-density lipoprotein

LDL-C:-Low-density lipoproteins

VLDL-C:-Very low-density lipoproteins

Data in table (5) shows the effect of rosemary and garlic at different levels on TC, TG, HDL,VLDL and $L D L$ in rats with induced liver cirrhosis. Diets supplemented with rosemary or garlic at different levels showed significant decrease $(P<0.05)$ in the mean levels of $T C, T G, V L D L$ and $L D L$, compared to the control positive group, while serum HLD-c was significantly increased $(P<0.05)$. Also diets supplemented with garlic and combination of rosemary and garlic showed significant decrease $(P<0.05)$ in the mean levels of TC, TG, VLDL and LDL, compared to the +ve group and increase in the level of HDL-c. It was observed that the more improvement of lipid profile was recorded at the groups fed on a mixture of rosemary and garlic

Table (6)

Effect of rosemary and garlic supplementation on blood cell parameters of rats with induced liver cirrhosis.

\begin{tabular}{l|c|c|c|c}
\hline Groups & Hemoglobin \% & RBCs (million/c.mm & $\begin{array}{c}\text { WBCs(thousands } \\
\text { /c.mm) }\end{array}$ & PCV\% \\
\hline Control (-ve) & $15.70 \pm 0.10^{\mathrm{a}}$ & $6.71 \pm 0.24^{\mathrm{a}}$ & $3.65 \pm 0.15^{\mathrm{c}}$ & $64.00 \pm 2.00^{\mathrm{a}}$ \\
\hline Control (+ve) & $7.90 \pm 0.40^{\mathrm{f}}$ & $2.42 \pm 0.42^{\mathrm{d}}$ & $11.50 \pm 0.90^{\mathrm{a}}$ & $26.00 \pm 5.00^{\mathrm{d}}$ \\
\hline Rosemary 5\% & $11.20 \pm 0.20^{\mathrm{e}}$ & $4.47 \pm 0.02^{\mathrm{c}}$ & $6.22 \pm 0.67^{\mathrm{b}}$ & $38.52 \pm 1.50^{\mathrm{b}}$ \\
\hline Rosemary 10\% & $12.65 \pm 0.25^{\mathrm{d}}$ & $4.58 \pm 0.08^{\mathrm{c}}$ & $6.35 \pm 0.25^{\mathrm{b}}$ & $43.00 \pm 2.00^{\mathrm{b}}$ \\
\hline Garlic 5\% & $12.97 \pm 0.12^{\mathrm{cd}}$ & $4.44 \pm 0.06^{\mathrm{c}}$ & $6.40 \pm 0.40^{\mathrm{b}}$ & $37.44 \pm 0.50^{\mathrm{b}}$ \\
\hline Garlic 10\% & $13.72 \pm 0.22^{\mathrm{bc}}$ & $4.75 \pm 0.25^{\mathrm{c}}$ & $7.10 \pm 0.01^{\mathrm{b}}$ & $41.00 \pm 2.00^{\mathrm{b}}$ \\
\hline Combination 5\% & $14.10 \pm 0.10^{\mathrm{b}}$ & $5.72 \pm 0.15^{\mathrm{b}}$ & $4.70 \pm 0.16^{\mathrm{c}}$ & $51.48 \pm 1.50^{\mathrm{b}}$ \\
\hline Combination10\% & $14.10 \pm 0.40^{\mathrm{b}}$ & $6.02 \pm 0.12^{\mathrm{b}}$ & $4.09 \pm 0.11^{\mathrm{c}}$ & $58.00 \pm 2.00^{\mathrm{ab}}$ \\
\hline
\end{tabular}

Values were expressed as Means $\pm \mathrm{SE}$.

Values at the same column with different letters are significantly different at $\mathrm{P}<0.05$.

Table (6) shows the effect of rosemary and garlic at different levels on blood cell parameters and Hemoglobin of rats with induced liver cirrhosis. The positive control group had significant decrease 


\section{Egypt. J. of Nutrition and Health Vol. 14 No. 1 January (2019)}

$(\mathrm{P}<0.05)$ in the mean value of $\mathrm{Hb}, \mathrm{RBCs}, \mathrm{PCV}$ and WBCs compared to the control negative group. On the other hand, the supplementation with rosemary,garlic and their combination significantly $(P<0.05)$ increased the mean level of RBCs, WBCs, PCV and Hemoglobin, compared to the positive control group. The highest increase in the tested parameters was observed at the groups that fed on a combination of rosemary and garlic.

\section{Discussion}

Chronic liver damage is a wide spread pathology characterized by a progressive evolution from steatosis, fibrosis and cirrhosis. The production of reactive oxygen species (ROS) is considered to be a major factor in oxidative cell njury. The antioxidant activity or the inhibition of free radicals generation is important in providing protection against such hepatic damage (Vitaglione et al., 2004).

Cirrhosis produces hepatocellular dysfunction and increased intrahepatic resistance to blood flow (Hung et al., 2006). The hepatic fibrosis developed due to increased accumulation of malondialdehyde(MDA), the stable end product of lipid peroxidation. MDA in this oxidative stress causes various diseases (Lee et al., 2004).

Medicinal plants were considered as the only form of health care readily available to the majority of human populations, and plants or plant derived products were used for medicinal purposes for centuries. Moreover, it is estimated that about $80 \%$ of the world population relies on botanical preparations as medicines to meet their health needs (Langneret al.,1998). This is reasoned by the fact that they are generally considered as safe and proved to be effective against certain ailments (Ganguly et al., 2003).

Rosemary contained the highest concentration of phenolic substances obtained from the leaves of the evergreen shrub rosemary (Okamura et al.,1994). The phenolic compounds responsible for rosemary antioxidant activity are mainly phenolic diterpenes such as carnosol, carnosic acid, rosmanol, epirosmanol and isorosmanol(Cuvelier et al.,1994 and Del Bano et al.,2003 ).Rosmanol is a potent antioxidant having inhibition effect of superoxide anion production, as well as lipid peroxidation and free radical scavenging activities(Haraguchi et al., 1995 and Escuder et al., 2002). The polyphenol, rosmarinic acid has 2 aromatic rings, each with $2-\mathrm{OH}$ groups that are capable of donating $\mathrm{H}$. and chelating metals. (Hra et al.,2000) reported that rosemary extract exhibited antioxidant activity superior to $\alpha$-tocopherol. Rosemary oleoresin has been reported to contain several components such as rosmanol, rosmariquinone, rosmaridiphenol, and carnosol that may be up to four times as effective as BHA and equal to BHT as an antioxidant (Houlihan et al., 1984 and Chang,1984).

Rosmarinic acid exhibits antioxidant and antiinflammatory effects (Halliwell,1996). Rosemary extracts are able to donate electrons to reactive radicals, converting them to more stable and on reactive species, therefore preventing them from reaching biomolecules, such as lipoproteins, polyunsaturated fatty acids, DNA, amino acids, proteins and sugars, in susceptible biological systems. Also, it was concluded that rosemary extracts have a high scavenging capacity of different types of reactive oxygen and nitrogen species, mostly free radicals, is thought to be one of the main mechanisms of the antioxidant action exhibited by phenolic phytochemicals (Moreno et al., 2006).

Dietary supplement because of its powerful antioxidant activity (Dorman et al., 2003) may function as an immunoenhancing antioxidant that could help alleviate the oxidative stress condition and will probably be effective in some stressed condition such as protein or antioxidant deficiency (Babuet al., 


\section{Omnia G.Refaat et al}

1998). Immunomodulation is one of the main targets for synthetic drugs and chemicals. However, its high cost, anticipated toxicity, and adverse event effects render it undesirable for the patients. In contrast, the use of herbal plants as health promoters is gaining increasing attention in both consumers and scientific circles. In the literature, several plants have been listed that exhibit immunomodulatory actions, like modulation of cytokine secretion; phagocytosis promotion and macrophage activation; immunoglobulinproduction;allergicreactionsandlymphocyte proliferation .Recently, garlic has been suggested asapromising candidate for maintaining the homeostasis of the immune system. Several studies have been carried out in animal models to examine the effect of different garlic components and formulations on immunomodulatory activities(Mahima et al.,2012).

The obtained results revealed that rosemary and garlic supplementation increased the immune functions, are in agreement with (Ad'hiahet al., 2004) who mentioned that the garlic has a long history of use as an immune system booster because of its antiseptic, anti-fungal and nutritive properties. It is a natural detoxicant protecting against bacterial and viral infections without any of the side-effects associated with antibiotics. In the current study, the protective effects of rosemary powder against $\mathrm{CCl}_{4}$ induced hepatotoxicity in adult male rats were investigated. In this respect, the effect of the extract on the liver functions and oxidative stress markers (hepatic glutathione reductase activity and malondialdehyde level) as well as histopathological changes of the liver were evaluated(Wang et al. 2008).

The current results are in agreement with the finding by (Liu et al.,2007)who reported that administration of rats with rosemary extract alleviated the deleterious effect of $\mathrm{CCl}_{4}$ on liver. Rosemary may act as a co-factor in the synthesis of biological endogenous antioxidant material (Reddy and Rao,2006).In the current study, high dose (as well as continuous administration) induced high degree of protection and improvement. This could be attributed to the high percentage of antioxidants in the high dose, which resulted in strongest inhibition of oxidative radicals from reaching the biological molecules. By the same manner, the continuous administration of rosemary extract besides $\mathrm{CCl}_{4}$ built a continuous resistant-barrier with more protection battery against oxidative radicals(Mata et al.,2007).

Rosemary inhibited and reduced the $\mathrm{CCl}_{4}$-induced hepatotoxicity inrats possibly by scavenging or blocking theformation of free radicals generated during $\mathrm{CCl}_{4}$ metabolism. These improving effects of rosemarycould be attributed to the bioactive constituentsthat alleviated the deleterious effect of $\mathrm{CCl}_{4}$ either by the well-known scavenging action orthe antioxidant properties that inhibited lipidperoxidation, stabilized the reactive radicals, preserve the cellular integrity and restrain theseverity of CCl4(Sotélo-Félix et al.,2002).

Garlic is one of the earliest documented examples of plants employed for treatment of disease andmaintenance of health.garlic also contains a high concentrationof selenium, which is responsible, part, for garlic'santioxidant and cancerpreventive effects. Hence, somegrowers add selenium to the soil to increase garlic'sselenium content(Amagase,2006).

Oral administration of rosemary leaf extract caused significant declines in the blood levels of triglycerides, total cholesterol, LDL-cholesterol, but increased HDLcholesterol. Moreover, it seemed that rosemary leaf extract had a hypolipidemic potential. This may be an indication of progressive metabolic control of rosemary leaf extract on mechanisms involved in elimination of the lipids from the body, this hypolipidemic properties have been confirmed in many plant species and plant products in medicinal use (Kono et al., 1992) 


\section{Egypt. J. of Nutrition and Health Vol. 14 No. 1 January (2019)}

The most important constituents of rosemary are caffeic acid and its derivatives such as rosmarinic acid. These compounds have antioxidant effect (Al-Sereiti et al., 1999). A variety of phenolic compounds, in addition to flavonoids, are found in fruit, vegetables and many herbs. The phenolic compounds (such as caffeic, ellagic, and ferulic acids, sesamol, and vanillin) inhibit atherosclerosis (Decker, 1995). In addition to a well documented role in reverse cholesterol transport, HDL-cholesterol has recently been recognized to have several other important cardio protective properties including the ability to protect LDL from oxidative modification (Nofer et al., 2002).the polyphenols glabridin (derived from licorice), rosmarinic acid or carnosic acid (derived from rosemary), as well as garlic (which contains a mixture on natural antioxidants) inhibited LDL oxidation in a dose-dependent manner(Fuhrman et al., 2000).Moreover, several studies showed that plant extracts lowered LDL oxidation. However, the present data demonstrated that consumption of rosemary can lead to reduction in the risk of hyperlipidemic symptoms and heart diseases. It can be concluded from presented results that rosemary have improved in the lipid profile. (Naidu and Thippeswamy, 2002).

Several studies have been carried out in animal models to examine the effect of different garlic components and formulations on immunomodulatory activities. Different studies have shown that garlic compounds are

able to perform antiapoptotic (Chen et al., 2014),antiparasitic (Gharavi et al.,2011),proapoptotic, anticancerigenic (Xu et al.,2014), andimmunomodulatory(Bauer et al., 2014)effects on different cells The presence of garlic compounds varies with respect to mode of garlic preparation and extraction as follows: (1) fresh bulbs main compounds are S-allyl-L-cysteine sulfoxide (alliin) and $\gamma$-glutamyl cysteine derivatives; (2) in steam distilled oils, sulfide family compounds are the main compounds; (3) powder from crushed and dried garlic contains alliin and diallyl disulfide (DADS); (4) macerates (ground garlic) are enriched extractions with sulfide family compounds, dithiines, and (EZ)-ajoene compounds, and (5) AGE (soaked, sliced, aged garlic extract in ethanol solution) contains Sallyl-L-cysteine (SAC) and S-allylmercaptocysteine (SAMC) (Trio et al.,2014)

Garlic compounds can be divided to several groups or families of compounds. Among these families, $y$-glutamyl cysteine derivatives, the primary precursor components of the alliin and allyl methyl cysteine (methiin) compound families (Amagase et al.,2001), that produced, by enzymatic action of alliinase (alliinlyase, EC: 4.4.1.4), the diallylthiosulfinate (Allicin) and allyl methyl thiosulfinate (AM) compound families (Augusti et al.,2012), which are precursors of severalorganosulfur compound families (i.e., the ajoene and dithiin families) (Lawson et al.,2005).Additionally, garlic preparations contain nonorgan sulfured compounds, such as tetrahydro-beta-carbolines(Ichikawa et al.,2006), fructans, and glucose-linked $\beta$ D-fructofuranosyl(Chandrashekar et al.,2011), identified in AGE preparations (Kim et al.,2013).

\section{Conclusions}

Rosemary inhibited and reduced the $\mathrm{CCl} 4$-induced hepatotoxicity in rats possibly by scavenging or blocking theformation of free radicals generated during CCl4metabolism. These improving effects of rosemarycould be attributed to the bioactive constituents that alleviated the deleterious effect of CCl4either by the well-known scavenging action or the antioxidant properties that inhibited lipid peroxidation, stabilized the reactive radicals,preserve the cellular integrity and restrain the severity of $\mathrm{CCl}$. The medicinal importance of garlic preparations has already been substantiated by the availability of garlic pearls for human use. Present study has shown that garlic has promising ani-inflammatory activity. 


\section{Omnia G.Refaat et al}

\section{References}

Ad'hiah, A. H.; Syhood, Y. D. and Shubber, E. K. (2004):

Inhibiting the hematological and cytogenetic effects of tamoxifen by alcoholic extract of garlic (Allium Sativum). Nucleus, 47: 10- 16.

Albers, N.;BendersonV.andwarnick G.(1983):

Enzmatic determination of high density lipoprotein cholesterol, Selected Methods,Clin. Chem,10:91-99.

Alexandrov, K.; Rojas, M. and Rolando, C. (2006):

DNA damage by benzo(a)pyrene in human cells is increased by cigarette smoke and decreased by a filter containing rosemary extract, which lowers free radicals, Cancer Res.66:1938-1945

AL-Sereiti, M.R.; Abu-Amer, K.M. and Sen, P. (1999):

Pharmacology of rosemary (Rosmarinusofficinalis Linn.) and its therapeutic potentials.Indian. $J$ EXP.Biol.37: 124-130.

Amagase H(2006).

Clarifying the real bioactive constituents of garlic.J Nutr;136:716S-25S.

Amagase H., Petesch B. L.,(2001):

Matsuura H., Kasuga S., Itakura Y. Intake of garlic and its bioactive components. Journal of Nutrition. ;131(supplement 3):955s-962s.

Artimage,G.Y. and Berry,W.G.(1987).

Statistical Methods $7^{\text {th }}$ Ed.Ames, lowa State University Press,39-63.

Augusti K. T., Jose R., Sajitha G. R., Augustine P.(2012):

A rethinking on the benefits and drawbacks of common antioxidants and a proposal to look for the antioxidants in Allium products as ideal agents: a review. Indian Journal of Clinical Biochemistry. ;27(1):6-20. doi: 10.1007/s12291-011-0146-y.

Babu US, Wiesenfeld PL, \& Jenkins MY.(1998).

Effect of dietary rosemary extract on cell-mediated immunity of young rats. Plant Foods for Human Nutrition, 53: 169-174.

Bauer D., Mazzio E., Soliman K. F., et al.(2014):

Diallyl disulfide inhibits TNF $\alpha$-induced CCL2 release by MDA-MB-231 cells. Anticancer Research. ;34(6):2763-2770.

Bonnel A.R.; Bunchorntavakul C.and Reddy K.R. (2011):

Immune dysfunction and infections in patients with cirrhosis. ClinGastroenterolHepatol; 9: 727-38.

Chang, C.H.;Chyau, C.C.; Hsieh, C.L.; Wu, Y.Y.; Ker, Y.B.; Tsen, H.Y. and Peng, R.Y. (2008):

Relevance of phenolic diterpene constituents toantioxidant activity of supercritical CO2 extract from the leaves ofrosemary, Nat Prod Res.22:76-90 


\section{Egypt. J. of Nutrition and Health Vol. 14 No. 1 January (2019)}

Chan JY, Yuen AC, Chan RY, Chan SW.(2013):

A review of the cardiovascular benefits and antioxidant properties of allicin. Phytother Res. ; 27:637-646.

Chandrashekar P. M., Prashanth K. V. H., Venkatesh Y. P.(2011):

Isolation, structural elucidation and immunomodulatory activity of fructans from aged garlic extract. Phytochemistry.;2(2-3):255-264. doi: 10.1016/.jphytochem..11.015.

Chen S., Tang Y., Qian Y., et al.(2014):

Allicin prevents $\mathrm{H}_{2} \mathrm{O}_{2}$-induced apoptosis of HUVECs by inhibiting an oxidative stress pathway. BMC Complementary and Alternative Medicine. ;14(1, article 321) doi: 10.1186/1472-6882-14-321.

Cuvelier, M.E., Berset, C. and Richard, H. (1994):

Antioxidant Constituents in Sage. Journal of Agricultural and Food Chemistry, 42, 665-669

Delves P. and Roitt I. (2000):

The immune system.Part 1. N Engl J Med; 343: 3-49.

Del Bano, M.J., Lorente, J., Castillo, J., Benavente-Garcia, O., Del Rio, J.A. and Ortuno, A. (2003): Phenolic Diterpenes, Flavones, and Rosmarinic Acid Distribution during the Development of Leaves, Flowers, Stems, and Roots of Rosmarinus.officinalis. Journal of Agricultural and Food Chemistry, 51, 4247-4253.

Decker EA. 1995.

The role of phenolics, conjugated linoleic acid, carnosine, and pyrroloquinolinequinone as nonessential dietary antioxidants. Nutr Rev, 53:49-56.

Dorman, A. Peltoketo, R. Hiltunen, M.J(2003):

TikkanenCharacterisation of the antioxidant properties of de-odorized aqueous extracts from selected Lamiaceae herbs Food Chem., 83, pp. 255-262.

Escuder, B., Torres, R., Lissi, E., Labbé, C. and Faini, F. (2002):

Antioxidant Capacity of Abietanes from SphaceleSalviae. Natural Product Letters, 16, 277-281.

Fridewald,W.T.;Leve R.I. and Fredrickson D.S.(1972);

Estimation of the concentration of low density lipoprotein separated by three different methods.Clin. Chem.,18:499-502.

Fuhrman B, Volkova N, Rosenblat M and Aviram M.(2000).

Lycopene synergistically inhibits LDL oxidation in combination with vitamin $\mathrm{E}$, glabridin, rosmarinic acid, carnosic acid, or garlic. Antioxid Redox Signal, 2:491-506.

Ganguly, N.K.; Medappa, N. and Srivastava, V.R. (2003).

Ginger: its role in xenobiotic metabolism. ICMR Bulletin, 33: 57-58.

Gharavi M. J., Nobakht M., Khademvatan S., Fani F., Bakhshayesh M., Roozbehani M.

The effect of aqueous garlic extract on interleukin-12 and 10 levels in Leishmania major (MRHO/IR/75/ER) infected macrophages. Iranian Journal of Public Health. 


\section{Omnia G.Refaat et al}

Halliwell, B. (1996):

An Evaluation of the Antioxidant and Antiviral Action of Extracts of Rosemary and Provencal Herbs. Food and Chemical Toxicology, 34, 449-456.

Haraguchi, H., Sito, T., Okamura, N., Yagi, A.( 1995).

Inhibition of lipid peroxidation and superoxide generation by diterpenoids from Romarinusofficinalis.Planta Medica61: 333-336.

Houlihan, C.M., Ho, C.T. and Chang, S.S. (1984):

Elucidation of the Chemical Structure of a Novel Antioxidant, Rosmaridiphenol, Isolated from Rosemary. Journal of the American Oil Chemists' Society, 61, 1036-1039

Hra, H.R., Hadolina, M., Knez, E. and Bauman, D. (2000):

Comparison of Antioxidative and Synergistic Effects of Rosemary Extract with $\alpha$-Tocopherol, AscorbylPalmitate and Citric Acid in Sunflower Oil. Food Chemistry, 71, 229- 233.

Hung, MY., Fu, TY., Shih, PH., Lee, CP., Du-Zhong, GC.( 2006).

oliv (Eucommiaulmoides) leaves inhibits CCl4-induced hepatic damage in rats. Food andChemical Toxicology 44:1424-1431.

Ichikawa M., Yoshida J., Ide N., Sasaoka T., Yamaguchi H., Ono K.

Tetrahydro- $\beta$-carboline derivatives in aged garlic extract show antioxidant properties. Journal of Nutrition. 2006;136(3, supplement):726s-731s

KaidoT;EgawaH;TsujiH;AshiharaE;Maekawa T, and Uemoto S. (2009).

In-hospital mortality in adult recipients of living donor liver transplantation: experience of 576 consecutive cases at a single center. Liver Transpl ; 15: 1420-5.

Kalpagam, P.P. and Nirmala, K. (2003):

Ginger, its role in xenobiotic metabolism, Hyderabad. ICMR Bulletin, 33: 57-58.

Kim S. R., Jung Y. R., An H. J., et al (2013).

Anti-wrinkle and anti-inflammatory effects of active garlic components and the inhibition of MMPs via NFKB signaling. PLoSONE. ;8(9)doi:10.1371/journal.pone.0073877.e73877.

Kono S, Shinchi K, Ikeda N, Yanai F and Imanishi K. (1992).

Green tea consumption and serum lipid profiles: a cross-sectional study in northern Kyushu, Japan. Prev Med,21: 526-531.

Langner, E.; Grifenberg, S. and Gruenwald, J. (1998):

Ginger history and use. Adv.Ther.15: 25-26.

Lawson L. D., Gardner C. D.(2005):

Composition, stability, and bioavailability of garlic products used in a clinical trial. Journal of Agricultural and Food Chemistry. ;53(16):6254-6261. doi: 10.1021/jf050536. 


\section{Egypt. J. of Nutrition and Health Vol. 14 No. 1 January (2019)}

Lee, KJ., Woo, ER., Choi, CY., Shin, DW., Lee, DG., You, HJ., Jeong, HG. (2004).

Protective effect of acteoside on carbon tetrachloride-induced hepatotoxicity. Life Science 74: 10511064.

Liu, F., Fei, R., Rao, HY., Cong, X., Ha, MH. Wei, L.( 2007).

The effects of endothelial progenitor cell transplantation in carbon tetrachloride induced hepatic fibrosis rats. Zhonghua Gan Zang Bing Za Zhi15: 589-192.

Mata, AT., Proenc, C., Ferreira, AR., Serralheiro, ML.,Nogueira, JM., Araujo, ME.( 2007).

Antioxidant and antiacetylcholinesterase activities of five plants used as Portuguese food spices.Food Chemistry 103: 778-786.

Mahima, Rahal A., Deb R., et al.(2012):

Immunomodulatory and therapeutic potentials of herbal, traditional/indigenous and ethnoveterinary medicines. Pakistan Journal ofBiological Sciences. ;15(16):754-774. doi: 10.3923/pjbs.2012.754.774.

Moreno, S., Scheyer T., Romano C.S., Vojnov A.A. (2006):

Antioxidant and antimicrobial activities of rosemary extracts linked to their polyphenol composition. Free Radical Research, 40 (2): 223-231.

Nakatani, N. and Inatani, R. (1984) :

Two Antioxidant Diterpenes from Rosemary (RosmarinusofficinalisL.) and a New Revised Structure for Rosmanol. Agricultural and Biological Chemistry, 48, 2081-2085.

Naidu KA and Thippeswamy NB.(2002).

Inhibition of human low density lipoprotein oxidation by active principles from spices.Mol Cell Biochem, 229:19-23.

Nofer JR, Kehrel B, Fobker M, Levkau B, Assmann G and von Eckardstein A. (2002).

HDL and arteriosclerosis: beyond reverse cholesterol transport. Atherosclerosis, 161:1-16.

Ochei, J. and Kolhatkar, A. (2008):

Medical Laboratory Sciences; Theory and Practice. Tata McGraw-Hill Publishing Co. Ltd. New Delhi; 321-324.

Okamura, N., Haraguchi, H., Hashimotok, K. and Yagi, A. (1994):

Flavonoids in RosmarinusofficinalisLeaves. Phytochemistry, 37, 1463-1466.

Ostertag, L.; Kennedy, N.; Kroon, P.; Duthie, G. and de Roos, B. (2010): Impact of dietary polyphenols on human platelet function a critical review of controlled dietary intervention studies. MolNutr Food Res., 54:60-81.

Peng, C.H.; Su, J.D.; Chyau, C.C.; Sung, T.Y.; Ho, S.S.; Peng, C.C. and Peng, R.Y. (2007). Supercritical fluid extracts of rosemary leaves exhibitpotent anti-inflammation and anti-tumor effects. BiosciBiotechnolBiochem.71:2223-2232.

Reeves,R.G; Nielsen, F.H. and Fahey,G.C.(1993):

AIN-93 Purified Diets for Labortory Rodents. J.Nutr.,123(1):1939-1951. 


\section{Omnia G.Refaat et al}

Reddy, JK.,Rao, MS. (2006).

Lipid metabolism and liver inflammation.II fatty liver disease and fatty acid oxidation.American Journal of Physiology-Gastrointestinal and Liver Physiology 290: 852-888.

Reitman, S. and S. Frankel.(1957)

A colorimetric method for the determination of serum glutamic oxaloacetic and glutamic pyruvic transaminases. Am. J. Clin. Pathol. 28, 56-63.

Richmond,N.(1973):

Colorimetric determination of total cholesterol and high density lipoprotein cholesterol(HDL-

C).Clin.Chem.,19:1350-1356.

Roy S.E. (1970):

Colorimetric determination of serum alkaline phosphatase. Clin Chem;16: 431 - 432.

Sotélo-Félix, Jl., Martinez-Fong, D., Muriel, P., Santillán, RL., Castillo, D., Yahuaca, P. (2002).

Evaluation of the effectiveness of Rosmarinusofficinalis (Lamiaceae) in the alleviation of carbon tetrachloride induced acute hepatotoxicity in the rat. Journal of Ethnopharmacology81: 145-154.

Trio P. Z., You S., He X., He J., Sakao K., Hou D.-X.(2014):

Chemopreventive functions and molecular mechanisms of garlicorganosulfur compounds. Food \& Function. ;5(5):833-844. doi: 10.1039/c3fo60479a

Visioli, F.; Poli, A. and Galli, C. (2015):

Anti-oxidant and other biological activities of phenols from olives and olive oil. Med Res Rev., 22:65-75.

Vitaglione, P., Morisco, F., Caporaso, N., Fogliano, V.( 2004).

Dietary antioxidant compounds and liver health.Critical Reviews in Food Science andNutrition 44: 575-586.

Wahlefeid,A.W.(1974):

Methods of enzymatic Analysis. Academic Press, Chapter,5:1831-1835.

Wang, T., Sunb, N., Zhang, W., Li, H., Lu, G., Yuan, B., Jiang, H., She, J., Zhang, C. (2008). Protective effects of dehydrocavidine on carbon tetrachlorideinduced acute hepatotoxicity in rats.Journal ofEthnopharmacology117: 300-308.

Weissman N.; Schoenbach E.B. and Armestead E.B. (1950):

J.biol. chem., 187:153.Cited in the Panphlet of Stanbio Laboratory, Boerne, Texas, USA.

Wieland E.; Olbricht C.J.; Susal C. and et al., (2010):

Biomarkers as a tool for management of immunosuppression in transplant patients. There Drug Monit ; 32: 560-72. 


\section{Egypt. J. of Nutrition and Health Vol. 14 No. 1 January (2019)}

Xu Y.-S., Feng J.-G., Zhang D., et al.(2014):

S-allylcysteine, a garlic derivative, suppresses proliferation and induces apoptosis in human ovarian cancer cells in vitro. ActaPharmacologicaSinica. ;35(2):267-274. doi: 10.1038/aps.2013.176

Yesil-Celiktas, O.; Nartop, P.; Gurel, A.; Bedir, E. and Vardar-Sukan, F. (2007):

Determination of phenolic content and antioxidant activity of extracts obtained from Rosmarinus officinalis' calli, J Plant Physiol.164:1536-1542.

Zhao Y.; Ma X.; Wang J.; He X.; Hu Y.; Zhang P.; Wang R.; Li R.; Gong M.; Luo S. and Xiao X. (2014): Curcumin Protects against CCl4-Induced Liver Fibrosis in Rats by Inhibiting HIF-1a Through an ERK-Dependent Pathway ., Molecules; 19: 18767-18780.

Ziva, J. and Pannall, P. (1984):

Clinical chemistry in diagnosis and treatment. Publ. Lloyd-Luke (Medical books), Londo, PP:348352. 


\section{Omnia G.Refaat et al}

تأثير الروزماري والثوم علي بعض قياسات الدم والوظائف المناعية علي التليف الكبدي للفئران

أمنيه جلال رفعت ، نعيم تحمل رابح ، الاء احمد عزت

قسم التغذية وعلوم الاطعمة ـ كلية الاقتصاد المنزلي- جامعة حلوان

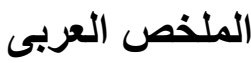

أجريت هذه الدراسة لمعرفة تأثير الروزماري والثوم على بعض قياسات الدم وبعض الوظائف المناعية

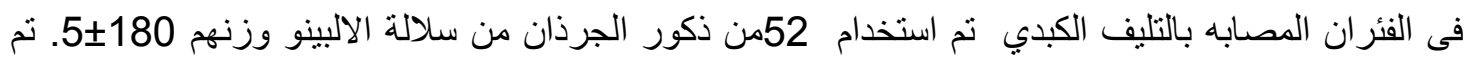

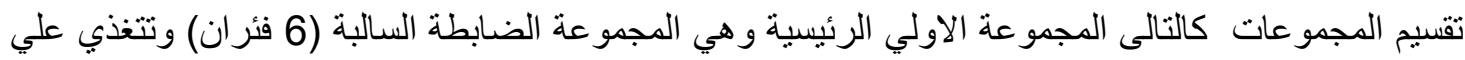

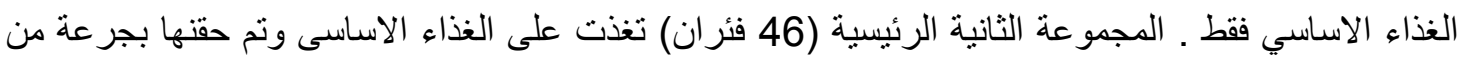

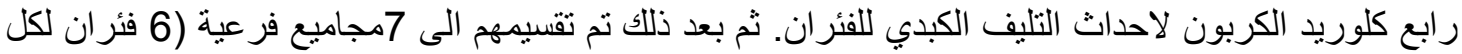

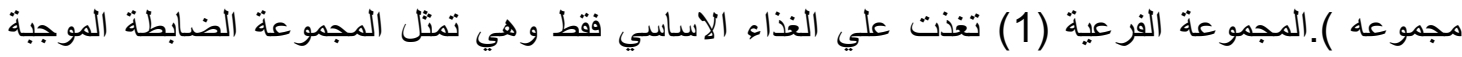



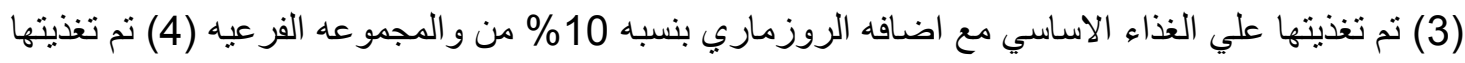

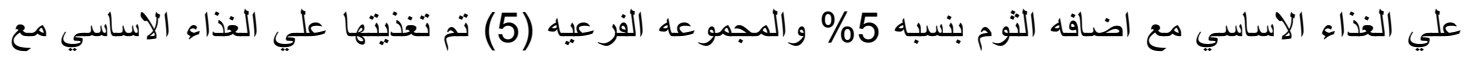

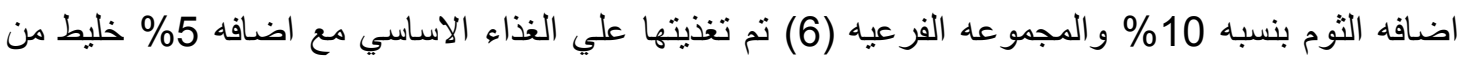

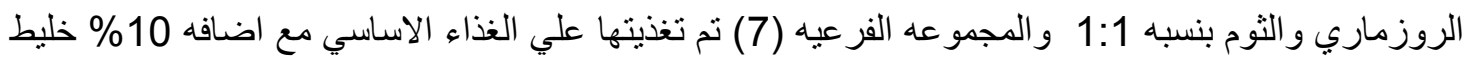

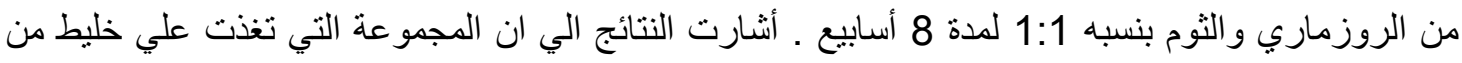

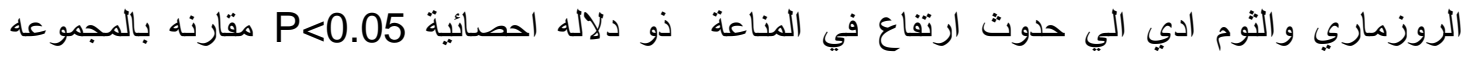

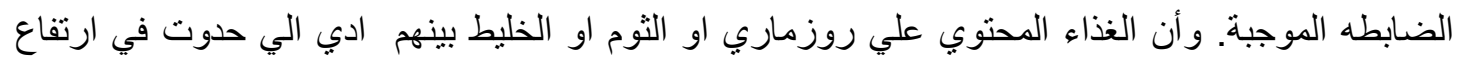

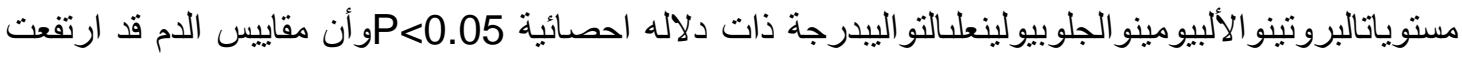

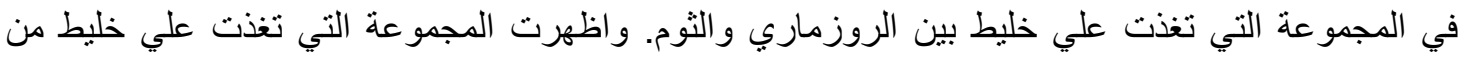

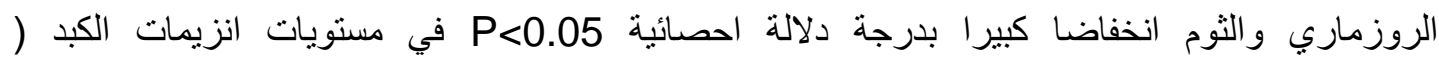



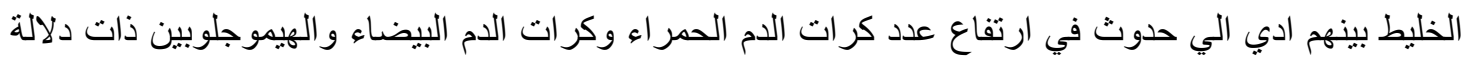

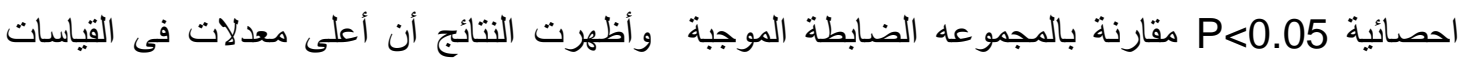

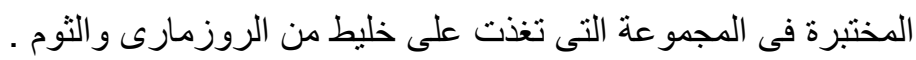

